\title{
(6) OPEN ACCESS \\ Fatal river drowning: the identification of research gaps through a systematic literature review
}

\author{
Amy E Peden, ${ }^{1,2}$ Richard C Franklin, ${ }^{1,2}$ Peter A Leggat ${ }^{2,3}$
}

\section{- Additional material is published online only. To view please visit the journal online (http://dx.doi.org/10.1136/ injuryprev-2015-041750). \\ ${ }^{1}$ Royal Life Saving Society- Australia, Broadway, New South Wales, Australia ${ }^{2}$ College of Public Health, Medical and Veterinary Sciences, James Cook University, Townsville, Queensland, Australia ${ }^{3}$ Research School of Population Health, College of Medicine, Biology and Environment, Australian National University, Canberra, Australian Capital Territory, Australia}

\section{Correspondence to} Amy E Peden, Royal Life Saving Society - Australia, PO Box 558, Broadway, NSW 2007, Australia; apeden@rlssa.org.au

Received 5 July 2015 Revised 17 November 2015 Accepted 28 November 2015 Published Online First

4 January 2016

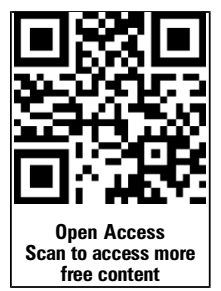

CrossMark

To cite: Peden $A E$, Franklin RC, Leggat PA. Inj Prev 2016;22:202-209.

\section{ABSTRACT \\ Introduction Drowning is a leading cause of} unintentional death. Rivers are a common location for drowning. Unlike other location-specific prevention efforts (home swimming pools and beaches), little is known about prevention targeting river drowning deaths. Methods A systematic literature review was undertaken using English language papers published between 1980 and 2014, exploring gaps in the literature, with a focus on epidemiology, risk factors and prevention strategies for river drowning.

Results Twenty-nine papers were deemed relevant to the study design including $21(72.4 \%)$ on epidemiology, $18(62.1 \%)$ on risk factors and $10(34.5 \%)$ that proposed strategies for prevention. Risk factors identified included age, falls into water, swimming, using watercraft, sex and alcohol.

Discussion Gaps were identified in the published literature. These included a lack of an agreed definition for rivers, rates for fatal river drowning (however, crude rates were calculated for 12 papers, ranging from 0.20 to 1.89 per 100000 people per annum), and consensus around risk factors, especially age. There was only one paper that explored a prevention programme; the remaining nine outlined proposed prevention activities. There is a need for studies into exposure patterns for rivers and an agreed definition (with consistent coding). Conclusions This systematic review has identified that river drowning deaths are an issue in many regions and countries around the world. Further work to address gaps in the published research to date would benefit prevention efforts.

\section{INTRODUCTION}

Drowning is a global public health issue, with the WHO estimating 372000 people die from drowning annually. ${ }^{1}$ The true burden of drowning is likely to be higher due to under-reporting, as victims are not hospitalised or cases are not recorded because of a lack of death collection tools in many low- and middle-income countries (LMICs). ${ }^{2}$ Some data on drowning are also excluded because of reporting methods such as the use of International Classification of Diseases (ICD) coding frameworks that mean drowning may be classified elsewhere or excluded if it is related to transportation or disaster. ${ }^{1}$

Drowning prevention interventions based on sitespecific locations are likely to have a greater impact and prove more successful than general strategies aimed at preventing drowning. ${ }^{3}$ A significant reduction in the number of drowning deaths among young children in private swimming pools has been achieved through over 30 years of focused work on the epidemiology and risk factors for drowning in private swimming pools among young children. ${ }^{4-8}$ A focus on beaches has also seen prevention efforts in that space be successful..$^{9-11}$ Strategies which target specific aquatic locations may also prove to be successful, as they allow ownership of the issue. In Australia for example, local councils are responsible for beaches and publicly owned swimming pools, and individuals are responsible for private swimming pools.

The ICD $10^{12}$ currently divides aquatic locations into the subsets of 'bathtub', 'swimming pool' and 'natural waterway'. The category of 'natural waterway' is broad and includes rivers, creeks, beaches, oceans, harbours, lakes and dams, thus not providing the fidelity to extract rivers. In 2004, the International Classification of External Causes of Injury (ICECI) Coordination and Maintenance Group articulated a classification for 'body of water' that allows the identification of river, stream (15.02.25). ${ }^{13}$ This information is needed to undertake site-specific research and develop targeted interventions.

To date, there has been limited research that has explored drowning in locations other than beaches and swimming pools. Inland waterways such as rivers, creeks, streams, lakes and dams regularly account for large proportions of drowning deaths, ${ }^{14-16}$ particularly in LMICs. In LMICs, drowning often occurs as a result of the activities associated with daily life ${ }^{17}$ rather than the recreational undertakings often being conducted before drowning in high-income countries (HICs). ${ }^{18-20}$

In Australia, rivers routinely claimed the largest number of lives in annual national drowning reports between 2011 and $2014,,^{21-24}$ and rivers accounted for $20.3 \%$ of unintentional fatal drowning in the 5 years between 2002 and $2007 .{ }^{4}$ Inland waterways (rivers, creeks, streams, lakes, dams and lagoons) have been deemed a key priority location by the Australian Water Safety Council (AWSC) where sustained action is required to achieve the aim of a 50\% reduction in national drowning deaths by the year $2020 .^{25} 26$

Proposed contributory factors for drowning in rivers include a lack of barriers controlling access to water, an absence of adult supervision for young children, poor swimming skills, minimal awareness of the dangers, the consumption of alcohol, transportation on water, a lack of safe water supply, and disasters related to flooding. ${ }^{1}$ Some proposed river prevention strategies include: community-based prevention; provision of safe places such as crèches for young children; basic swimming instruction for older children; increased public awareness of the vulnerability of children; legislation for safe 
boating; mitigation of flood risk; and continued research into priority areas. $^{1}$

\section{AIMS}

There is a need for a better understanding of the burden of river drowning as well as related risk factors to assist in the development of targeted and evidence-based strategies for prevention. This systematic review of peer-reviewed literature for fatal unintentional river drowning aims to:

- describe the epidemiology of fatal river drowning;

- describe risk factors for drowning in rivers;

- identify and critically analyse strategies for prevention; and

- identify gaps in research to date and propose priority areas where further work is required.

\section{METHODS}

This systematic literature review explored literature published in the English language between 1980 and 2014 using the databases Medline, Scopus, ScienceDirect, PsychInfo, SportDiscuss, the Cochrane Central Register for Controlled Trials, and SafetyLit.

For this study, the internationally accepted definition of drowning has been used $;^{27}$ however, as this study explored papers over a 35 -year period, not all papers used this definition. Any papers which used the words 'river', 'creek' or 'stream' (ie, those papers that said they were exploring unintentional fatal drowning in these locations) were included.

Initial search terms used were 'drown"' limited to English language, human and a published date range between 1 January 1980 and 31 December 2014. Searches were then refined to include 'drown"' and 'river"' or 'creek"' or 'stream"' or 'fresh water' limited to peer-reviewed publications (see online supplementary table S1a).

Two reviewers assessed the papers against the inclusion/exclusion criteria. Titles and abstracts were screened for these criteria by two reviewers (AEP, RCF). Where there was not consensus, there was the possibility of a third reviewer (PAL); however, this was not required. Review papers (ie, papers that did not present primary data; $n=1)^{28}$ were excluded from this study. A handsearch technique was used to identify any additional primary data sources in the paper's references. A manual search was completed for all references retained for data extraction excluding grey literature.

Papers were assessed according to the following inclusion/ exclusion criteria: (1) the drowning event was unintentional; (2) the literature included reference to rivers and/or creeks and/or streams. Exclusions included: intentional drowning (suicide) or homicide as a result of drowning; the forensic investigation of drowning (eg, autopsies and how to identify drowning in cases of fresh water drowning). Conference abstracts, even if published in the peer-reviewed literature, were excluded.

Papers where the main focus was flood-related drowning were excluded, as flooding differs from the normal river process with different risks and should therefore be dealt with separately to river drowning deaths during non-flooding periods. ${ }^{29} 30$

Risk factors were defined as an attribute (such as personal behaviour or lifestyle), environment (such as speed of water flow, depth of water, objects in the water) or an inborn or inherited characteristic (such as age, sex) that on the basis of evidence is known to increase the probability of a specified outcome, be it injury, death or disease. ${ }^{31}$ Preventive stratagems were defined as any activity aimed at reducing river drowning.

With respect to rivers (ie, rivers, creeks and streams), the following definitions from the Australian context were used. River was defined as '... a natural waterway that may be fed from other rivers or bodies of water draining water away from a 'catchment area' to another location....'32 'Rivers can vary in water flow, length, width and depth'. ${ }^{33}$ A creek was defined as 'a water body that may be fed by rivers and other creeks. A creek is generally smaller in size than a river and is often characterised by intermittent water flow. Creeks can be prone to more extreme conditions of stasis in drought and flash flooding after rainfall'. ${ }^{33}$ A stream was defined as 'a body of flowing water generally smaller than a river. May also be seasonal but may not always contain water'. 33

To reduce the size of tables 1 and 2 and to present the information consistently, categories (data sources and risk factors) have been given a numeric value-for example, death certificate is coded as 1 in table 1 . These can be found at the bottom of tables 1 and 2. Coding was used for the different hazards presented by rivers-for example, currents and drop offs were coded together as 'river characteristics' in table 2 and given the numeric code ' 10 '.

Where data on populations of the country or region being analysed, as well as the number of river drowning deaths, were made available, a crude rate of river drowning per 100000 population was calculated. Where a drowning rate was presented as well as the proportion of all drowning deaths that rivers accounted for as a percentage, this proportion was used on the overall drowning rate to calculate a crude river drowning rate per 100000 population.

The methodological quality of the papers that proposed strategies for prevention included in the review were assessed using the National Health and Medical Research Council (NHMRC) Levels of Evidence. ${ }^{55}$

\section{RESULTS}

A large number of papers were excluded because of a lack of specificity around unintentional fatal drowning specific to rivers. Several papers were included because they mentioned rivers as a category of location and their burden within the overall number of drowning deaths, but any further analysis, including identifying risk factors, could not be extracted from the broader grouping of 'freshwater'. 344447

Others were excluded because they did not focus on unintentional drowning. Papers where unintentional drowning in rivers could not be separated from fatal river drowning as a result of suicide and/or homicide were also excluded. ${ }^{56-61}$

Papers were excluded from the systematic review if they focused on both fatal and non-fatal drowning, such as hospital admissions due to drowning, without making distinction between the two by location, ${ }^{62}{ }^{63}$ as the present study expressly focused on fatal river drowning.

Initial search results returned 895 papers, and all papers were extracted into EndNote (see online supplementary figure S1) ${ }^{64}$ Duplicate papers $(n=224)$ were removed leaving 671 references. After a title search, 417 papers were removed. Abstracts were reviewed for 254 papers, and 116 papers were removed. The full text for 138 papers was assessed against the inclusion and exclusion criteria, and a further 114 papers were removed. Hand searches of the initial 24 papers included in the review were undertaken and identified a further five papers, resulting in 29 papers for review (see online supplementary table S1b). Of the 29 papers found, 21 (72.4\%) included epidemiological information, $18(62.1 \%)$ included information on risk factors for drowning in rivers, and 10 (34.5\%) were identified as proposing prevention strategies. 
Table 1 Relevant papers identifying prevalence of fatal drowning in rivers $(n=21)$

\begin{tabular}{|c|c|c|c|c|c|c|c|c|c|c|c|}
\hline Reference & $\begin{array}{l}\text { Country/area of } \\
\text { country }\end{array}$ & $\begin{array}{l}\text { Study } \\
\text { country } \\
\text { income } \\
\text { level }\end{array}$ & Year(s) & Population & $\begin{array}{l}\text { Data source/ } \\
\text { ICD8, } 9,10 \\
\text { none, unknown }\end{array}$ & Terminology & $\begin{array}{l}\text { Population } \\
\text { based }(\mathrm{Y} / \mathrm{N})\end{array}$ & $\begin{array}{l}\text { Number of } \\
\text { river drowning } \\
\text { deaths }\end{array}$ & $\begin{array}{l}\% \text { of river } \\
\text { drowning } \\
\text { deaths }\end{array}$ & $\begin{array}{l}\text { Rate/100 } 000 \\
\text { population }\end{array}$ & $\begin{array}{l}\text { Activity prior } \\
\text { to drowning }\end{array}$ \\
\hline $\begin{array}{l}\text { Brenner } \\
\text { et } a l^{34}\end{array}$ & USA & HIC & 1995 & Children aged $<20$ years & 1 (ICD9) & River, creek & Y & 235 & 17 & UTBC & Not discussed \\
\hline $\begin{array}{l}\text { Byard and } \\
\text { Lipsett }^{35}\end{array}$ & $\begin{array}{l}\text { Australia (South } \\
\text { Australia) }\end{array}$ & HIC & $\begin{array}{l}\text { March } 1963 \text { to } \\
\text { February } 1998\end{array}$ & Children $<2$ years of age & 3 (None) & River & $\begin{array}{l}\mathrm{N} \text {-Case } \\
\text { Series }\end{array}$ & 3 & 9 & UTBC & Not discussed \\
\hline Cass et $a l^{36}$ & $\begin{array}{l}\text { Australia (New } \\
\text { South Wales) }\end{array}$ & HIC & 1987-1990 & Children less than 15 years & 5 (None) & $\begin{array}{l}\text { Rivers and } \\
\text { creeks }\end{array}$ & $\mathrm{N}$; case series & 10 & 16 & UTBC & $\begin{array}{l}70 \% \text { wading near } \\
\text { shore (caught by } \\
\text { current or lost footing) }\end{array}$ \\
\hline Cass et $a l^{37}$ & $\begin{array}{l}\text { Australia (New } \\
\text { South Wales) }\end{array}$ & HIC & 1990-1995 & Children aged $0-14$ years & 2 (None) & Rivers & Y & 5 & 4 & UTBC & $\begin{array}{l}100 \% \text { playing or } \\
\text { swimming in the water }\end{array}$ \\
\hline Davis et $a l^{30}$ & USA (New Mexico) & HIC & 1975-1980 & People aged $0-24$ years & 1 (None) & Rivers & Y & 63 & 19 & $0.82^{*}$ & $\begin{array}{l}\text { 'Most victims involved } \\
\text { in activities near but } \\
\text { not in the water' }\end{array}$ \\
\hline $\begin{array}{l}\text { Dietz and } \\
\text { Baker }^{38}\end{array}$ & USA (Maryland) & HIC & 1972 & All accidental drowning deaths & 6 (None) & $\begin{array}{l}\text { Rivers or } \\
\text { creeks }\end{array}$ & Y & 61 & 52 & $1.56^{*}$ & $\begin{array}{l}37.7 \% \text { Boating } \\
31.1 \% \text { Swimming } \\
24.6 \% \text { Fell or stepped } \\
\text { into deep water }\end{array}$ \\
\hline Fang et $a l^{39}$ & $\begin{array}{l}\text { China (Xiamen city } \\
\text { and suburbs) }\end{array}$ & LMIC & 2001-2005 & Children aged $1-4$ years & $1(\mathrm{ICD} 9,10)$ & River & Y & 7 & 10 & $0.38^{*}$ & Not discussed \\
\hline Fife et $a l^{40}$ & USA (New Jersey) & HIC & 1981-1985 & $\begin{array}{l}\text { All immersion injuries leading } \\
\text { to hospital admission or death }\end{array}$ & 1 (ICD9) & River & Y & 66 & 16 & $0.21^{*}$ & Not discussed \\
\hline $\begin{array}{l}\text { Franklin } \\
\text { et } a l^{41}\end{array}$ & Australia & HIC & 1989-1992 & $\begin{array}{l}\text { Unintentional fatalities } \\
\text { occurring in the farm } \\
\text { environment }\end{array}$ & 2, 8 (Unknown) & $\begin{array}{l}\text { Rivers and } \\
\text { creeks }\end{array}$ & Y & 15 & 22 & UTBC & Not discussed \\
\hline Franklin et $a l^{4}$ & Australia & HIC & $\begin{array}{l}1 \text { Jul } 2002 \text { to } \\
30 \text { Jun } 2007\end{array}$ & $\begin{array}{l}\text { All unintentional fatal } \\
\text { drowning in Australia }\end{array}$ & 2, 8 (None) & Rivers & Y & 295 & 20 & $0.29^{*}$ & $\begin{array}{l}20.7 \% \text { Fall } \\
20.3 \% \text { Unknown } \\
18.6 \% \text { Other }\end{array}$ \\
\hline Iqbal et $\left.a\right|^{42}$ & Bangladesh (Matlab) & LMIC & $1985-2000$ & Children aged $1-4$ years & 7 (None) & Rivers & $\mathrm{Y}$ & 44 & 4.4 & UTBC & Not discussed \\
\hline $\begin{array}{l}\text { Kiakalayeh } \\
\text { et } a^{43}\end{array}$ & $\begin{array}{l}\text { Iran (Guilan and } \\
\text { Mazandran) }\end{array}$ & LMIC & $\begin{array}{l}20 \text { Mar } 2005 \text { to } \\
20 \text { Mar } 2006\end{array}$ & Resident (R) and tourists $(\mathrm{T})$ & 7, 1, 4 (ICD10) & River & Y & $85(75$ R 10 T) & $\begin{array}{l}25 \%(88.2 \% \\
\mathrm{R} 11.8 \% \mathrm{~T})\end{array}$ & $1.89 \dagger$ & Not discussed \\
\hline Lunetta et $a l^{44}$ & Finland & HIC & $1998-2000$ & All ages & $8(\mathrm{ICD} 8,9,10)$ & River & Y & 92 & 13.1 & $0.58^{*}$ & Not discussed \\
\hline $\begin{array}{l}\text { Newman } \\
\text { et }\left.a\right|^{45}\end{array}$ & $\begin{array}{l}\text { USA (five counties } \\
\text { of Washington } \\
\text { State) }\end{array}$ & HIC & 1987 to 1996 & $\begin{array}{l}\text { Individuals }>12 \text { months to } \\
19 \text { years who died of injuries } \\
\text { sustained while involved in } \\
\text { recreational wilderness activity }\end{array}$ & 6 (None) & River & $\mathrm{N}$; case series & 15 & 37.5 & UTBC & $\begin{array}{l}\text { 46.7\% Swimming } \\
33.3 \% \text { Falls } \\
20.0 \% \text { Watercraft }\end{array}$ \\
\hline Nixon et $a l^{5}$ & $\begin{array}{l}\text { Australia (Brisbane } \\
\text { (Queensland)) }\end{array}$ & HIC & 1967-1981 & Childhood (0-15 years) & 99 (None) & Creeks, rivers & Y & 20 & 15.0 & $0.53^{*}$ & Not discussed \\
\hline $0^{\prime}$ Hare et $a{ }^{46}$ & New Zealand & HIC & 1983-1995 & $\begin{array}{l}\text { Deaths as a result of } \\
\text { recreational river rafting }\end{array}$ & 8 (ICD9) & Rivers & $\mathrm{N}$; case series & 31 & 93.9 & UTBC & $100 \%$ Watercraft \\
\hline $\begin{array}{l}\text { Patteta and } \\
\text { Biddinger }^{47}\end{array}$ & $\begin{array}{l}\text { USA (North } \\
\text { Carolina) }\end{array}$ & HIC & 1980-1984 & All people & 1 (None) & River or creek & Y & 309 & 29.4 & $0.94^{*}$ & Not discussed \\
\hline $\begin{array}{l}\text { Rahman } \\
\text { et } a l^{15}\end{array}$ & $\begin{array}{l}\text { Bangladesh (rural } \\
\text { and urban } \\
\text { communities) }\end{array}$ & LMIC & 2003 & Children 0-17 & 4 (None) & River & Y & 96 & 5.2 & $1.42^{*}$ & Not discussed \\
\hline
\end{tabular}




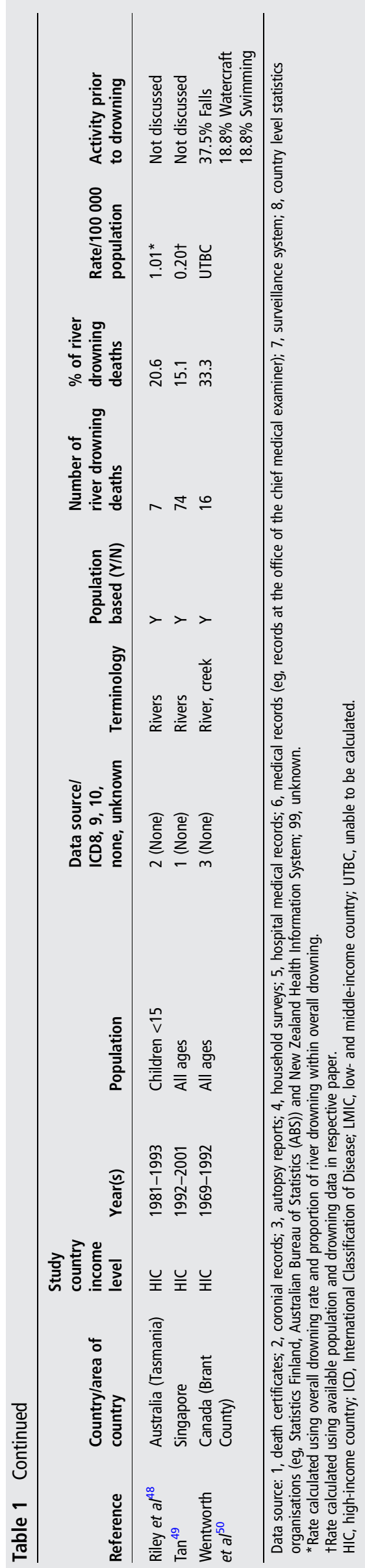

Table 2 Relevant papers discussing risk factors for fatal drowning in rivers $(n=18)$

\begin{tabular}{|c|c|c|c|}
\hline Reference & Country/area of country & $\begin{array}{l}\text { Risk } \\
\text { factors }\end{array}$ & $\begin{array}{l}\text { Type of } \\
\text { study }\end{array}$ \\
\hline Ahmed et $a l^{51}$ & Bangladesh (Matlab) & 1,2 & $\begin{array}{l}\text { Population } \\
\text { based }\end{array}$ \\
\hline $\begin{array}{l}\text { Byard and } \\
\text { Lipsett }^{35}\end{array}$ & Australia (South Australia) & 4 & Case series \\
\hline Cass et $a l^{36}$ & Australia (New South Wales) & $8,10,18$ & Case series \\
\hline Cass et $a l^{37}$ & Australia (New South Wales) & $2,9,4$ & Case series \\
\hline Davis et $a P^{30}$ & USA (New Mexico) & 6,12 & $\begin{array}{l}\text { Population } \\
\text { based }\end{array}$ \\
\hline Fang et $a l^{39}$ & China (Xiamen city and suburbs) & 11 & $\begin{array}{l}\text { Population } \\
\text { based }\end{array}$ \\
\hline Franklin et $a l^{4}$ & Australia & $\begin{array}{l}12,6,7 \\
99\end{array}$ & $\begin{array}{l}\text { Population } \\
\text { based }\end{array}$ \\
\hline $\begin{array}{l}\text { Howland } \\
\text { et }\left.a\right|^{52}\end{array}$ & USA (Massachusetts) & 3 & $\begin{array}{l}\text { Telephone } \\
\text { survey }\end{array}$ \\
\hline Kauffman ${ }^{53}$ & $\begin{array}{l}\text { USA (Potomac River-West } \\
\text { Virginia, Maryland, Virginia, } \\
\text { Washington DC) }\end{array}$ & $\begin{array}{l}10,3,13 \\
18\end{array}$ & Case studies \\
\hline $\begin{array}{l}\text { Kiakalayeh } \\
\text { et } a l^{43}\end{array}$ & Iran (Guilan and Mazandran) & 17,12 & $\begin{array}{l}\text { Population } \\
\text { based }\end{array}$ \\
\hline Lunetta et $a l^{44}$ & Finland & 3 & $\begin{array}{l}\text { Population } \\
\text { based }\end{array}$ \\
\hline $\begin{array}{l}\text { Newman } \\
\text { et } a l^{45}\end{array}$ & $\begin{array}{l}\text { USA (five counties of } \\
\text { Washington State) }\end{array}$ & $\begin{array}{l}4,12,1 \\
5,7,14\end{array}$ & Case series \\
\hline Nixon et $a l^{5}$ & Australia (Brisbane (Queensland)) & 16 & Unknown \\
\hline $0^{\prime}$ Hare et $a l^{46}$ & New Zealand & 14,17 & Case series \\
\hline $\begin{array}{l}\text { Patetta and } \\
\text { Biddinger }^{47}\end{array}$ & USA (North Carolina) & 3 & $\begin{array}{l}\text { Population } \\
\text { based }\end{array}$ \\
\hline Riley et $a l^{48}$ & Australia (Tasmania) & 12 & Case series \\
\hline Sorey et $a l^{54}$ & USA & 15 & Case series \\
\hline $\begin{array}{l}\text { Wentworth } \\
\text { et } a l^{50}\end{array}$ & Canada (Brant County) & $\begin{array}{l}4,12,3 \\
6,7\end{array}$ & $\begin{array}{l}\text { Population } \\
\text { based }\end{array}$ \\
\hline
\end{tabular}

Risk factor coding: 1, summer months; 2, exposure; 3, alcohol; 4, being male; 5 , daylight hours; 6 , falls into water; 7 , swimming; 8, rurality; 9 , risk-taking behaviour; 10 , river characteristics (eg, caught in current, lost footing due to steep/sharp drop offs); 11 , lack of swimming ability; 12 , age; 13 , not wearing lifejackets; 14 , using watercraft; 15 , river tree rope swings; 16 , lower survival rates/more likely to experience a bad outcome; 17, resident of the area they drowned in (as opposed to a tourist); 18 , lack of river knowledge; 19 , monsoon period; 20 , absence of supervision; 99, unknown activity.

\section{Epidemiology}

Of the 21 papers, seven (33.3\%) examined drowning data at a national level, and 14 at a sub-national level. The time periods ranged from a single year ${ }^{153438} 43$ to 35 years. ${ }^{35}$ Nine studies $(42.9 \%)$ focused on all ages, and $10(47.6 \%)$ focused on children. Two papers focused on specific populations (farm environment $^{41}$ and recreational river rafting $\left.{ }^{46}\right)$. Eight papers (38.1\%) included information on activity prior to drowning. Falls were the most common activity, followed by swimming and watercraft (table 1).

The three most common data sources used were death certificates (33.3\%), country level statistics organisations (19.0\%) and autopsy reports $(9.5 \%)$. Three papers used multiple data sources, two used a combination of coronial records and country level statistics organisations, ${ }^{41}$ and the other a combination of a surveillance system, death certificates and household surveys $^{43}$ (table 1 ).

The burden of drowning in rivers ranged from 3.8\% of all drowning deaths among children $0-14$ years in the Australian state of New South Wales ${ }^{37}$ to $52.0 \%$ in the USA state of Maryland in $1972 .{ }^{38}$ The crude rate of river drowning per 
100000 population varied from $0.38^{39}$ to $1.89^{43}$ in LMICs and from $0.20^{49}$ to $1.56^{38}$ in HICs (table 1 ).

\section{Risk factors}

Risk factors identified included: age (33.3\%); activity prior to drowning (33.3\%), of which falls into water (16.7\%), swimming $(16.7 \%)$ and using watercraft $(11.1 \%)$ were identified; being male (22.2\%); alcohol (27.8\%). Where age was a risk factor, the age groups identified were children $\left(5-14\right.$ years), ${ }^{48}$ adolescents, ${ }^{30}$ teenagers (12-18 years), ${ }^{45}$ young people (under 39 years), ${ }^{50}$ adults (18-49 years) ${ }^{4}$ and older people $(70+$ years $) .{ }^{43}$ Common groupings of risk factors included age and falls ${ }^{4} 3050$ and age, being male and swimming ${ }^{45} 50$ (table 2).

\section{Strategies for prevention}

There were nine papers proposing prevention strategies (table 3 ), and only one paper that explored the effectiveness of a river drowning prevention strategy. This paper observed the use of lifejackets by children at three popular local river beaches in Sacramento County, California. ${ }^{65}$ Of the nine papers which proposed prevention strategies, education was mentioned in six (66.7\%). Other proposed strategies included fencing, ${ }^{43} 3767$ signage, ${ }^{53}$ depth gauges, ${ }^{53}$ grills, ${ }^{43}$ covers, ${ }^{67}$ lifejackets, ${ }^{34} 45535465$ legislation and enforcement, ${ }^{65}$ and supervision. ${ }^{45} 62$

Proposed education-based prevention strategies included targeting education at older boys who were deemed more likely to be risk takers ${ }^{37}$ and young men on the risks of jumping from a height into water. ${ }^{66}$ Education on river conditions (depth of the river, velocity and deceptiveness) through the use of public service announcements was suggested. ${ }^{53}$ Encouraging river users to recognise water conditions such as currents and the impact on personal swimming ability ${ }^{45}$ was also recommended, as well as education for users of river tree rope swings about the potential risk of injury and for land managers about associated liabilities. $^{54}$ Evidence for papers citing proposed strategies for prevention was generally low, classified as level IV in $90.0 \%$ of papers, with only one paper being classified as level III-3. ${ }^{65}$

\section{DISCUSSION}

There is currently no clear consistent definition of 'river', making this review challenging. Consideration was given to the types of terms used to classify rivers as well as whether any papers attempted to define river, creek and stream locations. No papers included in this systematic review included information as to how rivers were defined. As such, in this paper it is the first time that a definition of the aquatic location of 'river' has been provided.

The exploration of river drowning is also challenging given the use of ICD coding that does not allow the isolation of studies associated with rivers. ${ }^{12}$ Being unable to quantify the burden of drowning in rivers makes the identification of riverspecific risk factors difficult. This impedes the development of location-based strategies for prevention. For example, in Australia, $64.3 \%$ of drowning deaths would occur in the ICD10-coded natural waterways of beach, ocean, lake and river. $^{24}$

Table 3 Relevant papers discussing proposed prevention strategies for fatal river drowning $(n=10)$

\begin{tabular}{|c|c|c|c|}
\hline Reference & Country/area of country & Prevention strategies & Level of evidence \\
\hline $\begin{array}{l}\text { Wintemute } \\
\text { et } a l^{65}\end{array}$ & $\begin{array}{l}\text { USA (observation sessions at } 3 \text { popular } \\
\text { local river beaches in Sacramento County, } \\
\text { California) }\end{array}$ & $\begin{array}{l}\text { Lifejackets made available for use without charge by swimmers at popular local } \\
\text { river beaches. } \\
\text { Statutory requirements: ordinances making it unlawful for parents or guardians } \\
\text { to allow children under } 13 \text { to enter rivers without lifejackets } \\
\text { Enforcement: higher lifejacket use is likely if enforced }\end{array}$ & $\begin{array}{l}\text { III-3 } \\
\text { Observational study and } \\
\text { expert opinion }\end{array}$ \\
\hline Reference & Country & Proposed prevention strategies & Level of evidence \\
\hline Brenner et $a l^{34}$ & USA & Lifejackets (when boating or playing near rivers) & $\begin{array}{l}\text { IV } \\
\text { Population-based study }\end{array}$ \\
\hline Cass et $a P^{37}$ & Australia (New South Wales) & $\begin{array}{l}\text { Education (targeted at older boys who are prone to risk-taking behaviour) } \\
\text { Engineering: fencing house to separate from hazard) }\end{array}$ & $\begin{array}{l}\text { IV } \\
\text { Expert opinion and case } \\
\text { series }\end{array}$ \\
\hline Kauffman ${ }^{53}$ & $\begin{array}{l}\text { USA (Potomac River-West Virginia, } \\
\text { Maryland, Virginia, Washington DC) }\end{array}$ & $\begin{array}{l}\text { Education: public service announcements of river conditions } \\
\text { Engineering: river depth gauges with interpretive signs } \\
\text { Administrative: signage on risks of river } \\
\text { Lifejackets as a prevention strategy }\end{array}$ & $\begin{array}{l}\text { IV } \\
\text { Expert opinion and case } \\
\text { series }\end{array}$ \\
\hline $\begin{array}{l}\text { Kemp and } \\
\text { Sibert }^{62}\end{array}$ & UK & $\begin{array}{l}\text { Supervision } \\
\text { Engineering: restrict access for swimming } \\
\text { Education: youth organisations not to organise swimming parties in rivers }\end{array}$ & $\begin{array}{l}\text { IV } \\
\text { Expert opinion and case } \\
\text { series }\end{array}$ \\
\hline $\begin{array}{l}\text { Kiakalayeh } \\
\text { et } a l^{43}\end{array}$ & Iran (Guilan and Mazandran) & Engineering: fences and grills & $\begin{array}{l}\text { IV } \\
\text { Expert opinion }\end{array}$ \\
\hline Moran $^{66}$ & Australia and New Zealand & $\begin{array}{l}\text { Education: young men about safe behaviours and inherent risks of jumping from } \\
\text { a height into water }\end{array}$ & $\begin{array}{l}\text { IV } \\
\text { Expert opinion }\end{array}$ \\
\hline Nakahara et al ${ }^{67}$ & Japan & Engineering: fences or covers for rivers & $\begin{array}{l}\text { IV } \\
\text { Population-based study }\end{array}$ \\
\hline Newman et $a /^{45}$ & USA (five counties of Washington State) & $\begin{array}{l}\text { Education: recognition of water conditions such as currents and personal } \\
\text { swimming ability } \\
\text { Basic water safety instruction for children } \\
\text { Supervision and lifejacket use should be emphasised when children are around } \\
\text { water }\end{array}$ & $\begin{array}{l}\text { IV } \\
\text { Case series }\end{array}$ \\
\hline Sorey et $a l^{54}$ & USA & $\begin{array}{l}\text { Education: awareness of injuries or liabilities } \\
\text { Lifejackets, especially for non-swimmers }\end{array}$ & $\begin{array}{l}\text { IV } \\
\text { Expert opinion and case } \\
\text { series }\end{array}$ \\
\hline
\end{tabular}




\section{Epidemiology}

While rivers were found to be the leading location for drowning in several papers, ${ }^{45668}$ the majority of papers focused on the burden of drowning generally - of which river drowning may be a component-rather than national population-level epidemiological studies on the prevalence of river drowning. No papers provided a rate for drowning deaths in rivers; however, 12 papers provided sufficient information to calculate a crude fatal drowning rate, which ranged from $0.20^{49}$ to $1.89^{43}$ per 100000 population.

Future studies of fatal drowning should provide rates based on location to allow comparison between papers. It should be noted that population-based rates do not take exposure into account. Future studies should also aim to identify exposure at river locations to calculate more accurate drowning rates.

Age groups found to be at risk ranged from children (5-14 years $)^{48}$ to older people $\left(70+\right.$ years).$^{43}$ Further work needs to be undertaken to determine which age groups are at risk and why there is such variance. We postulate that this variance is due to exposure.

Exploration of common activities prior to drowning was rare, with only seven papers including information of this type. Activities included falls into water, ${ }^{4} 305069$ swimming, ${ }^{4} 4550$ using watercraft ${ }^{46}{ }^{45}$ and river tree rope swings. ${ }^{54}$ Two papers also identified unique considerations for the prevention of fatal river drowning, namely the farm environment ${ }^{41}$ and those who drown as a result of recreational river rafting. ${ }^{46}$ These papers identify the need for epidemiological studies to isolate the different causal factors for fatal river drowning in order to identify applicable prevention strategies.

\section{Risk factors}

Rivers have been identified as being a particularly risky location, with drownings more likely to result in a fatal outcome. ${ }^{5}$ Being male was highlighted as a risk factor, ${ }^{35} 374550$ as was age (although consensus was lacking). ${ }^{4} 3038484550$ Teenagers and young adults, most commonly male, and their propensity towards risk-taking behaviour were identified in several papers. ${ }^{30} 4566$

Other risk factors included: a lack of swimming ability; ${ }^{39}$ underestimating the risk that river conditions can pose $;{ }^{53}$ local residents (rather than tourists); ${ }^{43}{ }^{46}$ rurality of river location; ${ }^{483651}$ use of tree rope swings; ${ }^{54}$ and reluctance to use lifejackets. ${ }^{53}$ Children who play in and around rivers without adult supervision were also recognised as being at increased risk of drowning, ${ }^{70}$ although adult supervision may still not be effective in preventing river drowning deaths in children in some circumstances. ${ }^{45}$

Alcohol was acknowledged as a risk factor for drowning in rivers in a number of papers, ${ }^{44} 4750525369$ with one paper finding $74.0 \%$ of all river drowning deaths to be alcohol-related. ${ }^{44}$

Much of the evidence to support the proposed risk factors for river drowning is based on population-based studies or case series. Several risk factors identified for river drowning are known risk factors for drowning, such as being male, the consumption of alcohol, and exposure to the hazard. Evaluations of proposed prevention strategies are needed to determine if strategies addressing general drowning risk factors are successful in the specific context of river drowning prevention. Other risk factors for river drowning identified in this systematic review may warrant further testing, such as lack of swimming ability, lack of knowledge of rivers as a hazard, and river characteristics.
Exposure studies will also assist in identifying if a lack of consensus based on age as a risk factor is due to the variety of activities being undertaken prior to drowning in rivers. We postulate that rivers are multipurpose settings, which poses a challenge for prevention.

\section{Strategies for prevention}

There was only one study that discussed the evaluation of a prevention strategy for fatal river drowning through the use of lifejackets; however, the strategy was found to increase lifejacket use rather than prevent drowning. ${ }^{65}$ Five papers made reference to strategies proposed in the WHO Global Report on Drowning, ${ }^{1}$ most commonly restricting access to water through barriers, ${ }^{43} 376267$ and basic swimming instruction for children; ${ }^{45}$ however, none had been evaluated. Engineering solutions to restrict access such as grills ${ }^{43}$ and covers ${ }^{67}$ were not well explained in the literature and are unlikely to be successful in open water environments such as rivers. There were nine other papers which discussed possible strategies and these were grouped around education, restricting access, lifejackets, signage, depth gauges, swimming skills and adult supervision of children. $^{34} 3743455354626766$

While supervision was commonly mentioned as a prevention strategy, one study stated that none of the victims were on their own when they drowned, teenagers usually were with peers and younger children with adults. ${ }^{45}$ This has important implications for drowning prevention in rivers, as the presence of a 'supervisor' may not necessarily ensure supervision. Supervision as a prevention strategy should be clearly explained to include elements of responsibility (adult, sober), proximity, attention, continuity ${ }^{8} 7172$ and preparedness. ${ }^{8}$ There would be benefit in a consistently applied universal definition for supervision. ${ }^{8}$

There are a range of contributory factors that lead to drowning in rivers. Any interventions designed to be successful in preventing drowning in such aquatic locations must be evidence based and take into account factors such as exposure. ${ }^{73}$ Further research is required to determine if strategies that are in place at other aquatic locations, such as lifeguard patrols at beaches, would be successful at river locations.

Ninety per cent of papers proposing strategies for the prevention of river drowning were classified as level IV, which represents a low level of quality. Well-designed and executed studies evaluating proposed strategies for prevention of river drowning are needed.

\section{Additional research gaps}

National population-based studies that specifically focus on the prevalence of river drowning among all age groups are urgently required. These studies should focus on the burden of river drowning as well as quantifying proposed risk factors such as age, sex, alcohol and activity prior to drowning among others. There is a need for more accurate exposure data (based on visitation information) to allow more sophisticated rates of river drowning per 100000 visitations to be calculated. Most papers identified through this review focused on drowning overall, with only a small subsection of the paper including data and risk factors specific to rivers.

The sphere of river drowning prevention would also benefit from the use of an agreed definition to allow comparison across studies. Further specificity is required within coding mechanisms for location that go beyond the current coding structures within the ICD codes for location of drowning. 


\section{Limitations}

- No papers identified in this systematic review included a rate per 100000 for river drowning. Where a general rate of drowning per 100000 and a proportion of drowning deaths in rivers was included in the paper, we were able to calculate a crude rate of river drowning per 100000 people. These crude drowning rates are not age adjusted and may not be as accurate if calculated from primary data. It does, however, for the first time provide a comparison between papers.

- Although the English language limit was used, the search did identify papers (three) where the abstract was in the English language, but the full paper was in a language other than English (Portuguese, Chinese and Turkish). Of these, only one paper identified the burden of river drowning, accounting for $6.3 \%$ of drowning in a tourism region of Turkey between 2002 and $2006 .^{74}$ These three studies were found as part of the overall 895 papers, but were excluded on the basis of not being in the English language.

- The majority of the papers included in this review are from HICs, with only four papers from three LMICs (China, Iran and Bangladesh) being deemed to fit the inclusion criteria.

- This systematic review excluded grey literature (ie, non-peer-reviewed literature such as research published by international, government and non-governmental organisations) and may not have identified all studies in the area, thus publication bias may be present.

\section{CONCLUSION}

This review found that the crude rate of river drowning ranged from 0.20 to 1.89 per 100000 population and that common risk factors were being male, age, alcohol and rurality of river locations. Data coding limitations that restrict our ability to extract river drowning deaths from within the ICD code of

\section{What is already known on the subject}

- Fatal drowning is a global public health issue, with the WHO estimating 372000 drowning deaths annually.

- Fatal river drowning is a hitherto little researched topic.

- Location-specific prevention efforts for drowning are likely to be more effective, as has been seen in the prevention of child drowning in private swimming pools.

\section{What this study adds}

- Calculated fatal crude river drowning rates ranged from 0.20 to 1.89 per 100000 population.

- A range of risk factors are identified in the literature such as sex, age groups ranging from young children to older people, and the consumption of alcohol; however, there is little consensus.

- Gaps identified include the need for a consistently applied definition for rivers, the need for national population level studies into the prevalence and prevention of river drowning, studies on exposure patterns for rivers, and well-evaluated prevention strategies (commonly proposed strategies include wearing lifejackets, restricting access through fencing, supervision of children, and education about risk). natural waterways makes identifying location-specific burden almost impossible.

This systematic review has identified that river drowning deaths are an issue in many regions and countries around the world. Further research is warranted, as well as the development, implementation and evaluation of prevention strategies. Future work should focus on the gaps identified in the research including: the development of an agreed definition; national population level studies into the prevalence of fatal river drowning; studies that quantify risk factors; studies that explore exposure; and studies that provide evidence for effective prevention.

Twitter Follow Richard Franklin at @Franklin_R_C, follow Amy E Peden at @amyepeden, follow Royal Life Saving at @RoyalLifeSaving

Acknowledgements This research is supported by the Royal Life Saving SocietyAustralia to aid in the reduction of drowning. Research at the Royal Life Saving Society-Australia is supported by the Australian Government.

Contributors AEP and RCF conceptualised and designed the study. AEP conducted the analysis, drafted the initial manuscript and approved the final manuscript as submitted. RCF carried out quality control of analysis, reviewed and revised the manuscript and approved the final manuscript submitted. PAL reviewed and revised the manuscript and approved the final manuscript as submitted.

Competing interests None declared.

Provenance and peer review Not commissioned; externally peer reviewed.

Open Access This is an Open Access article distributed in accordance with the Creative Commons Attribution Non Commercial (CC BY-NC 4.0) license, which permits others to distribute, remix, adapt, build upon this work non-commercially, and license their derivative works on different terms, provided the original work is properly cited and the use is non-commercial. See: http://creativecommons.org/ licenses/by-nc/4.0/

\section{REFERENCES}

1 World Health Organisation. Global report on drowning: preventing a leading killer. Geneva: World Health Organisation, 2014. http://apps.who.int/iris/bitstream/10665/ 143893/1/9789241564786 eng.pdf?ua=1\&ua=1 (accessed 22 May 2015).

2 Lin C, Wang Y, Lu T, et al. Unintentional drowning mortality, by age and body of water: an analysis of 60 countries. Inj Prev 2015:21:e43-350.

3 Thompson DC, Rivara FP. Pool fencing for preventing drowning in children. Cochrane Database Syst Rev 2000;(2):CD001047. http://onlinelibrary.wiley.com/doi/ 10.1002/14651858.CD001047/pdf (accessed 22 May 2015).

4 Franklin RC, Scarr JP, Pearn JH. Reducing drowning deaths: the continued challenge of immersion fatalities in Australia. Med J Aust 2010;192:123-6.

5 Nixon J, Pearn J, Wilkey l, et al. Fifteen years of child drowning - a 1967-1981 analysis of all fatal cases from the Brisbane drowning study and an 11 year study of consecutive near-drowning cases. Accid Anal Prev 1986;18:199-203.

6 Nixon JW, Pearn JH, Dugdale AE. Swimming ability of children: a survey of 4000 Queensland children in a high drowning region. Med J Aust 1979;2:271-2.

7 Pearn J, Nixon J. Swimming pool immersion accidents: an analysis from the Brisbane Drowning Study. Med J Aust 1977;1:432-7.

8 Bugeja L, Franklin RC. An analysis of stratagems to reduce drowning deaths of young children in private swimming pools and spas in Victoria, Australia. Int J Inj Contr Saf Promot 2013;20:282-94.

9 Morgan D, Ozanne-Smith J, Triggs T. Descriptive epidemiology of drowning deaths in a surf beach swimmer and surfer population. Inj Prev 2008;14:62-5.

10 Sherker $\mathrm{S}$, Brander R, Finch $\mathrm{C}$, et al. Why Australia needs an effective national campaign to reduce coastal drowning. I Sci Med Sport 2008;11:81-3.

11 Williamson A, Hatfield J, Sherker S, et al. A comparison of attitudes and knowledge of beach safety in Australia for beachgoers, rural residents and international tourists. Aust N Z Health J Public Health 2012;36:385-91.

12 National Centre for Classification in Health Australia. ICD-10-AM tabular list of diseases. Sydney: National Centre for Classification in Health, Australia. 2004

$13 \mathrm{ICECI}$ Coordination and Management Group. International Classification of External Causes of Injuries (ICECI) version 1.2. Adelaide: Consumer Safety Institute, Amsterdam and AlHW National Injury Surveillance Unit, 2004.

14 Soko B. Fiji Drowning Report 2012: Water Safety Council of Fiji, 2013. http:// watersafety.org.fj/wp-content/uploads/2014/11/Fiji-Drowning-Report-2012 LR-FINAL-20130626.pdf (accessed 1 Jun 2015).

15 Rahman A, Mashreky SR, Chowdhury SM, et al. Analysis of the childhood fatal drowning situation in Bangladesh: exploring prevention measures for low-income countries. Inj Prev 2009;15:75-9.

16 Statens Institut for Folkesundhed. Denmark National Drowning Report 2001-2012. 2014. 
17 Linnan M, Rahman A, Scarr J, et al. Child Drowning: Evidence for a newly recognized cause of child mortality in low and middle income countries in Asia. Working Paper 2012-07, Special Series on Child Injury No 2 Florence: UNICEF Office of Research, 2012. http://www.unicef-irc.org/publications/pdf/drowning.pdf (accessed 1 Jun 2015).

18 Buzzacott $\mathrm{P}$, Rosenberg M, Pikora T. Western Australian recreational scuba diving fatalities, 1992 to 2005. Aust N Z J Public Health 2009;33:212-4.

19 Johnston BD. Prevention of open water drowning while boating. Inj Prev 2014;20:219-9.

20 Pitt R, Balanda KP. Childhood drowning and near-drowning in Brisbane: the contribution of domestic pools. Med J Aust 1991;154:661-5.

21 Royal Life Saving Society -Australia. Royal Life Saving National Drowning Report 2011. Sydney: Royal Life Saving Society—Australia, 2011. http://www. royallifesaving.com.au/_data/assets/pdf_file/0005/4001/2011-Drowning-Report.pdf (accessed 25 May 2015).

22 Royal Life Saving Society—Australia. Royal Life Saving National Drowning Report 2012. Sydney: Royal Life Saving Society—Australia. 2012. http://www. royallifesaving.com.au/_data/assets/pdf_file/0006/4002/2012-Drowning-Report.pdf (accessed 25 May 2015).

23 Royal Life Saving Society -Australia. Royal Life Saving National Drowning Report 2013. Sydney: Royal Life Saving Society—Australia, 2013. http://www. royallifesaving.com.au/_data/assets/pdf_file/0003/9759/RLS_NationalDrowning Report_2013.pdf (accessed 25 May 2015).

24 Royal Life Saving Society_Australia. Royal Life Saving National Drowning Report 2014. Sydney: Royal Life Saving Society—Australia, 2014. http://www. royallifesaving.com.au/_data/assets/pdf_file/0007/11995/RLS_NDR2014_LR.pdf (accessed 25 May 2015).

25 Australian Water Safety Council. Australian water safety strategy 2008-11. Sydney: Australian Water Safety Council, 2008. http://www.watersafety.com.au/Portals/0/ AWSC\%20Stragegy\%202012-15/AWSC\%20Strategy\%202008-2011/Australian\% 20Water\%20Safety\%20Strategy\%202008-11.pdf (accessed 25 May 2015).

26 Australian Water Safety Council. Australian water safety strategy 2012-15. Sydney: Australian Water Safety Council, 2012. http://www.watersafety.com.au/Portals/0/ AWSC\%20Stragegy\%202012-15/AWSC_Strategy2012_Brochure\%20-\%20Lowres. pdf (accessed 25 May 2015).

27 van Beeck E, Branche CM, Szpilman D, et al. A new definition of drowning: towards documentation and prevention of a global public health problem. Bull World Health Organ 2005;83:853-6.

28 Wilson I, McDermott $\mathrm{H}$, Munir $\mathrm{F}$, et al. Injuries, ill-health and fatalities in white water rafting and white water paddling. Sports Med 2013;43:65-75.

29 Jonkman SN, Kelman I. An analysis of the causes and circumstances of flood disaster deaths. Disasters 2005;29:75-97.

30 Davis S, Ledman J, Kilgore J. Drownings of children and youth in a desert state. West J Med 1985;143:196-201.

31 Porta M. A dictionary of epidemiology. 4th edn. Oxford University Press, 2008.

32 Royal Life Saving Drowning Database Definitions and Coding Manual. In: Peden AE, ed. Sydney: Royal Life Saving Society—Australia, 2014:p41-42.

33 Australian Water Safety Council. A guide to water safety essentials for local governments. Sydney, 2008. http://www.watersafety.com.au/Reports.aspx (accessed 28 May 2015).

34 Brenner RA, Trumble AC, Smith GS, et al. Where children drown, United States, 1995. Pediatrics 2001:108:85-9.

35 Byard RW, Lipsett J. Drowning deaths in toddlers and preambulatory children in South Australia. Am J Forensic Med Pathol 1999;20:328-32.

36 Cass D, Ross F, Grattan-Smith T. Child drownings: a changing pattern. Med J Aust 1991;154:163-5.

37 Cass DT, Ross F, Lam LT. Childhood drowning in New South Wales 1990-1995: a population-based study. Med J Aust 1996;165:610-12.

38 Dietz PE, Baker SP. Drowning: epidemiology and prevention. Am J Public Health 1974;64:303-12.

39 Fang Y, Dai L, Jaung MS, et al. Child drowning deaths in Xiamen city and suburbs, People's Republic of China, 2001-5. Inj Prev 2007;13:339-43.

40 Fife D, Scipio S, Crane GL. Fatal and nonfatal immersion injuries among New Jersey residents. Am J Prev Med 1991;7:189-93.

41 Franklin RC, Mitchell RJ, Driscoll TR, et al. Non-work-related farm fatalities in Australia, 1989-1992. J Agric Saf Health 2001;7:229-39.

42 Iqbal A, Shirin T, Ahmed T, et al. Childhood mortality due to drowning in rural Matlab of Bangladesh: magnitude of the problem and proposed solutions. J Health Popul Nutr 2007;25:370-6.

43 Kiakalayeh AD, Mohammadi R, Ekman DS, et al. Unintentional drowning in northern Iran: a population-based study. Accid Anal Prev 2008;40:1977-81.
44 Lunetta P, Smith GS, Pentilä A, et al. Unintentional drowning in Finland 19702000: a population-based study. Int I Epidemiol 2004;33:1053-63.

45 Newman LM, Diekema DS, Shubkin CD, et al. Pediatric wilderness recreational deaths in western Washington State. Ann Emerg Med 1998;32:687-92.

46 O'Hare D, Chalmers D, Arnold NA, et al. Mortality and morbidity in white water rafting in New Zealand. Inj Control Saf Promot 2002;9:193-8.

47 Patetta MJ, Biddinger PW. Characteristics of drowning deaths in North Carolina. Public Health Rep 1988;103:406-11.

48 Riley MD, Larson A, Langford J. Drowning fatalities of children in Tasmania: differences from national data. Aust N Z J Public Health 1996;20:547-9.

49 Tan RMK. The epidemiology and prevention of drowning in Singapore. Singapore Med J 2004;45:324-9.

50 Wentworth P, Croal AE, Jentz LA, et al. Water-related deaths in Brant County 1969-1992: A review of fifty-seven cases. J Can Soc Forensic Sci 1993;26:1-18.

51 Ahmed MK, Rahman M, van Ginneken J. Epidemiology of child deaths due to drowning in Matlab, Bangladesh. Int I Epidemiol 1999;28:306-11.

52 Howland J, Mangione T, Hingson R, et al. A pilot survey of aquatic activities and related consumption of alcohol, with implications for drowning. Public Health Rep 1990;105:415-9.

53 Kauffman RB. The drowning trap: on the Potomac River most people drown well below flood levels. Trends 1992;29:39-47.

54 Sorey WH, Cassidy LD, Crout J, et al. River tree rope swing injuries. South Med J 2008;101:699-702.

55 Australian Government National Health and Medical Research Council (NHMRC). NHMRC additional levels of evidence and grades for recommendations for developers of guidelines. Secondary NHMRC additional levels of evidence and grades for recommendations for developers of guidelines 2005. http://www.nhmrc. gov.au/ files nhmrc/file/quidelines/levels_grades05.pdf

56 Mahabalesh $\mathrm{S}$. Profile of drowning deaths in Mangalore, a coastal city of Karnataka. Med-Leg Update 2005;5:39-42.

57 Seleye-Fubara D, Nicholas EE, Esse I. Drowning in the Niger Delta region of Nigeria: an autopsy study of 85 cases. Niger Postgrad Med J 2012;19:111-4.

58 Nichter MA, Everett PB. Profile of drowning victims in a coastal community. J Fla Med Assoc 1989;76:253-6.

59 Rathod H, Pathak A, Mangal HM. Epidemiological study of drowning deaths in Rajkot, Gujarat. J Forensic Med Toxicol 2008;25:1-4.

60 Rodrigues EJ. Medico legal study of drowning cases in Goa Medical College Hospital, Bambolim, Goa. Int J Med Toxicol Legal Med 2006;8:7-10.

61 Suresh Kumar Shetty B, Shetty M. Epidemiology of drowning in Mangalore, a coastal Taluk of South India. J Forensic Leg Med 2007;14:410-15.

62 Kemp A, Sibert JR. Drowning and near drowning in children in the United Kingdom: lessons for prevention. BMJ 1992;304:1143-6.

63 Wallis B, Watt K, Franklin RC, et al. Out of sight but not out of mind: rural drowning in Queensland. Inj Prev 2012;18(Suppl 1):A136.

64 Moher D, Liberati A, Tetzlaff J, et al. Preferred reporting items for systematic reviews and meta-analyses: the PRISMA statement. BMJ 2009;339:b2535.

65 Wintemute GJ, Anton A, Andrada E, et al. Compliance with an ordinance requiring the use of personal flotation devices by children in public waterways. West J Emerg Med 2013;14:200-3.

66 Moran K. Jumping to (fatal) conclusions? An analysis of video film on a social networking web site of recreational jumping from height into water. Int I Inj Contr Saf Promot 2014:21:47-53.

67 Nakahara S, Ichikawa M, Wakai S. Drowning deaths among Japanese children aged 1-4 years: different trends due to different risk reductions. Inj Prev 2004:10:125-6.

68 Kanchan T, Monteiro FNP. An analysis of accidental drowning fatalities in Manipal, South India. Inj Prev 2012;18(Suppl 1):A132.

69 Lasbeur L, Girard D, Thelot B. Epidemiological surveillance of drownings: a national survey in France, 1 June-30 September 2009. Inj Prev 2010;16:A125.

70 Rolloque A, Consunji RJ, Perez MT, et al. Cutcut project: a response to the prevention of child drowning in the Philippines. Inj Prev 2012;18(Suppl 1): A132.

71 Morrongiello BA, Pickett W, Berg RL, et al. Adult supervision and pediatric injuries in the agricultural worksite. Accid Anal Prev 2008;40:1149-56.

72 Saluja G, Brenner R, Morrongiello BA, et al. The role of supervision in child injury risk: definition, conceptual and measurement issues. Inj Control Saf Promot 2004;11:17-22.

73 Mitchell $R$, Haddrill $K$. From the bush to the beach: water safety in rural and remote New South Wales. Aust I Rural Health 2004;12:246-50.

74 Lakadamyali H, Doğan T. Investigation of drowning cases in a tourism region of Turkey. Turk Klinikleri J Med Sci 2008;28:143-8. 